\title{
Organophosphorus flame retardants in surface and effluent water samples from the Vaal River catchment, South Africa: levels and risk to aquatic life
}

\author{
TB Chokwe ${ }^{1 *}$ and SM Mporetji ${ }^{1}$ \\ ${ }^{1}$ Scientific Services, Rand Water, P.O. Box 3526, Vereeniging, 1930, South Africa
}

\begin{abstract}
The occurrence and risk assessment of seven organophosphorus flame retardants (OPFRs) in surface water samples within the Vaal River catchment in South Africa were investigated. Wastewater treatment works effluents as the potential sources of OPFRs in surface water were also analysed. In surface water, tris-(chloro-propyl)-phosphate (TCPP) - the total of the three TCPP isomers studied, and tris-(2, 3 dibromo-propyl)-phosphate (TDBPP) were the most abundant OPFRs, with mean concentrations of $276 \mathrm{ng} / \mathrm{L}$ and $227 \mathrm{ng} / \mathrm{L}$; respectively. In effluent water samples, the most abundant OPFR was TCPP with a mean concentration of $700 \mathrm{ng} / \mathrm{L}$. A high detection frequency $(>80 \%)$ was observed for six of the seven OPFRs with tris- $(1$, 3- dichloro-propyl)-phosphate (TDCPP) detection frequency being the lowest at $17 \%$. Assessment of risk to aquatic organisms using risk quotients based on measured environmental concentrations (MEC) and predicted no-effect concentrations (PNEC) ranged from no significant risk (for algae, daphnia and fish) to low potential for adverse effects (for algae and fish).
\end{abstract}

Keywords: organophosphorus flame retardants, water samples, concentrations, risk, Vaal River

\section{INTRODUCTION}

Organophosphorus compounds (OPs) are esters of phosphoric acid that are increasingly used as plasticizers and by the flame retardant industry to replace regulated brominated diphenyl ethers (pentaBDE, octaBDE and decaBDE) (Kim et al., 2013; Wei et al., 2015). OP production and application has thus been increasing in recent years (Morris et al., 2014) leading to their widespread occurrence in the environment, including air (Shoeib et al., 2014), dust (Abafe and Martincigh, 2014), river water (Cristale et al., 2013), drinking water (Li et al., 2014), biota (Gao et al., 2014), soil (Eguchi et al., 2013) and biosolids (Zeng et al., 2014a, 2014b). OPs have been used as additives in furniture, textile coating, upholstery, electronics, paints, polyvinyl chloride (PVC) plastics, polyurethane foams, lubricants and hydraulic fluids (Abafe and Martincigh, 2014; Wei et al., 2015; Zeng et al., 2014b). The chlorinated alkylphosphates such as tris (1-chloro2-propyl) phosphate (TCPP), tri (3-chloropropyl) phosphate (3-TCPP), tris (1,3-dichloro-2-propyl) phosphate (TDCPP) and tris (2-chloroethyl) phosphate (TCEP) are used mainly in polyurethane foams, electronic equipment, textiles, plastic and building materials, while the non-derivatized organophosphates such as triphenyl phosphates (TPP) are mainly used as lubricants and to regulate pore sizes such as in concrete (Marklund et al., 2005; EFRA, 2006; Van der Veen and De Boer, 2012; Kim et al., 2013; Abafe and Martincigh, 2014). The presence of both chlorine and phosphorus is advantageous for the optimum nonflammability, working in both the solid and gaseous phases.

Ongoing toxicological studies have shown several toxic effects of these compounds, such as the potential for ecological and human health concerns of neurotoxin and carcinogenic nature (Abafe and Martincigh, 2014; Cristale et al., 2013). The extent and magnitude of OPs occurrence in the environment, combined with striking structural similarity to toxic organophosphorus pesticides, has led to public concern over

*Corresponding author, email: tlouchokwe6@gmail.com

Received 4 April 2018; accepted in revised form 2 July 2019 risks posed by these substances (Oliveri et al., 2015; Wei et al., 2015). TCEP has been found to have teratogenic and haemolytic effects and has carcinogenic potential in rats and mice (BethHubner, 1999; Sato et al., 1997). TPP was found to show adverse biological effect (Lin, 2009) and can cause contact dermatitis in humans and is a potent inhibitor of human carboxyl esterase (WHO, 1991). One study found that, although developmental exposure to TDCPP did not cause behavioural effects or alter monoamine levels in larval zebrafish, females exposed to TDCPP through to adulthood showed depressed levels of both dopamine and serotonin later in life (Wang et al., 2015). Correspondingly, in vivo work has shown that TDCPP can affect cellular function in the PC12 cell line and increase its differentiation into both cholinergic and dopaminergic cell types (Dishaw et al., 2011).

The environmental concerns associated with the use of these compounds as flame retardants is that they have the potential to be released into surface water bodies either directly or via industrial and wastewater treatment works (WWTWs) discharges (Meyer and Bester, 2004), and from atmospheric depositions (Möller et al., 2011). In this regard they have been found in water at levels of ng to $\mu \mathrm{g} / \mathrm{L}$ (Cristale et al., 2013; Wang et al., 2011). The levels and distribution of contaminants in the surface and effluent water samples could reflect the pollution status in the environment. Thus, in the present study, 15 representative surface water samples located in the Vaal River catchment and 6 WWTWs effluents were selected as target sites to gain insight regarding levels and risk assessment of OPs in the aquatic environment.

\section{MATERIALS AND METHODS}

\section{Chemicals and reagents}

Approximately, $1.2 \mathrm{~mL}$ each of tris (2-chloroethyl) phosphate (TCEP), tris (1-chloropropyl) phosphate (1-TCPP), tris (3-chloropropyl) phosphate (3-TCPP), tris (1-chloro-2-propyl) phosphate (TCPP), tris (1,3-dichloro-2-propyl) phosphate (TDCPP), triphenyl phosphate (TPP), tris (2, 3 dibromopropyl) phosphate (TDBPP) of analytical grade were purchased from 
AccuStandard; USA. The solvents acetone, dichloromethane (DCM), methanol (MeOH), ethyl acetate (EtOAc), methyl tertiary-butyl ether $(\mathrm{M} t \mathrm{BE})$ and hexane used in the study were of GC grade purchased from Merck, Johannesburg, South Africa, and were used without further purification. Strata $\mathrm{X}$ (33 and $100 \mu \mathrm{m}), \mathrm{C}_{18}$ and styrene divinyl benzene (SDVB) cartridges were purchased from Separations, Johannesburg, South Africa. PestiCarb cartridges were purchased from Chemetrix, Johannesburg, South Africa. Helium as He 5.5 pure was purchased from Air Products, Vereeniging, South Africa.

\section{Sample collection}

Water samples were collected from the Vaal River catchment within the Free State (Sites 1-4), Gauteng (Sites 5-7) and Mpumalanga (Sites 8-14) Provinces of South Africa, as shown in Figure 1. The selected sampling sites were classified as hotspots for pollution because of activities within the catchment area (Chokwe et al., 2017). Some of the key activities within the catchment include flows from wastewater treatment works, stock farming, and irrigation agriculture, as well as an overall increase in human population within the subcatchment area. Water samples (of $2.5 \mathrm{~L}$ ) were collected from each of the 21 sampling sites during October - December 2017.

\section{Extraction of analytes from simulated water samples}

Solid-phase extraction (SPE) was used as the isolation technique throughout the experiment. Five different types of SPE cartridges (Strata X $33 \mu \mathrm{m}$, Strata X $100 \mu \mathrm{m}$, PestiCarb, C18 and SDVB) were tested for the pre-concentration of halogenated organophosphorus and un-halogenated organophosphorus compounds from water samples. Satisfactory results were obtained with SDVB cartridges with elution by $3 \times 2 \mathrm{~mL}$ EtOAc: MtBE (4:1). Before use, the SPE cartridge was conditioned with $12 \mathrm{~mL}$ of hexane, $12 \mathrm{~mL}$ of DCM, $12 \mathrm{~mL}$ of MeOH and $12 \mathrm{~mL}$ of MilliQ water. About $500 \mathrm{~mL}$ of MilliQ water preserved with $5 \mathrm{~mL} \mathrm{MeOH}$ was spiked with $100 \mu \mathrm{L}$ of organic OPFRs standard mixture and extracted at a flow rate of approximately $10 \mathrm{~mL} / \mathrm{min}$. After passing the sample through the cartridge, the cartridge was dried under vacuum for $1 \mathrm{~h}$. The compounds were eluted with $3 \times 2 \mathrm{~mL}$ of mixture of (4: 1$)$ EtOAc: $\mathrm{M} t \mathrm{BE}$. The eluates were evaporated to dryness under a gentle stream of nitrogen at $40^{\circ} \mathrm{C}$. Parathion D10 $(200 \mathrm{ng} / \mathrm{L})$ as an internal standard was added and the volume made up to $200 \mu \mathrm{L}$ with ethyl acetate (EtOAc). $2 \mu \mathrm{L}$ of the extracts and internal standards was injected into the GC-MS.

\section{Extraction of analytes from water samples}

The optimized procedure obtained using the simulated water samples was used to isolate the targeted compounds from surface and effluent water samples within the Vaal River catchment. During the analysis of both types of water samples, $500 \mathrm{~mL}$ of surface water and $500 \mathrm{~mL}$ of effluent water samples were spiked with $100 \mu \mathrm{L}$ of OPFRs standard mixture in triplicate to check the robustness of the developed method.

\section{Instrumentation and GC-MS conditions}

An Agilent 6890 GC equipped with 5975 mass selective detector (MSD) was used for GC-MS analysis. The GC was equipped with an Agilent 7683 Series Injector autosampler. The injection

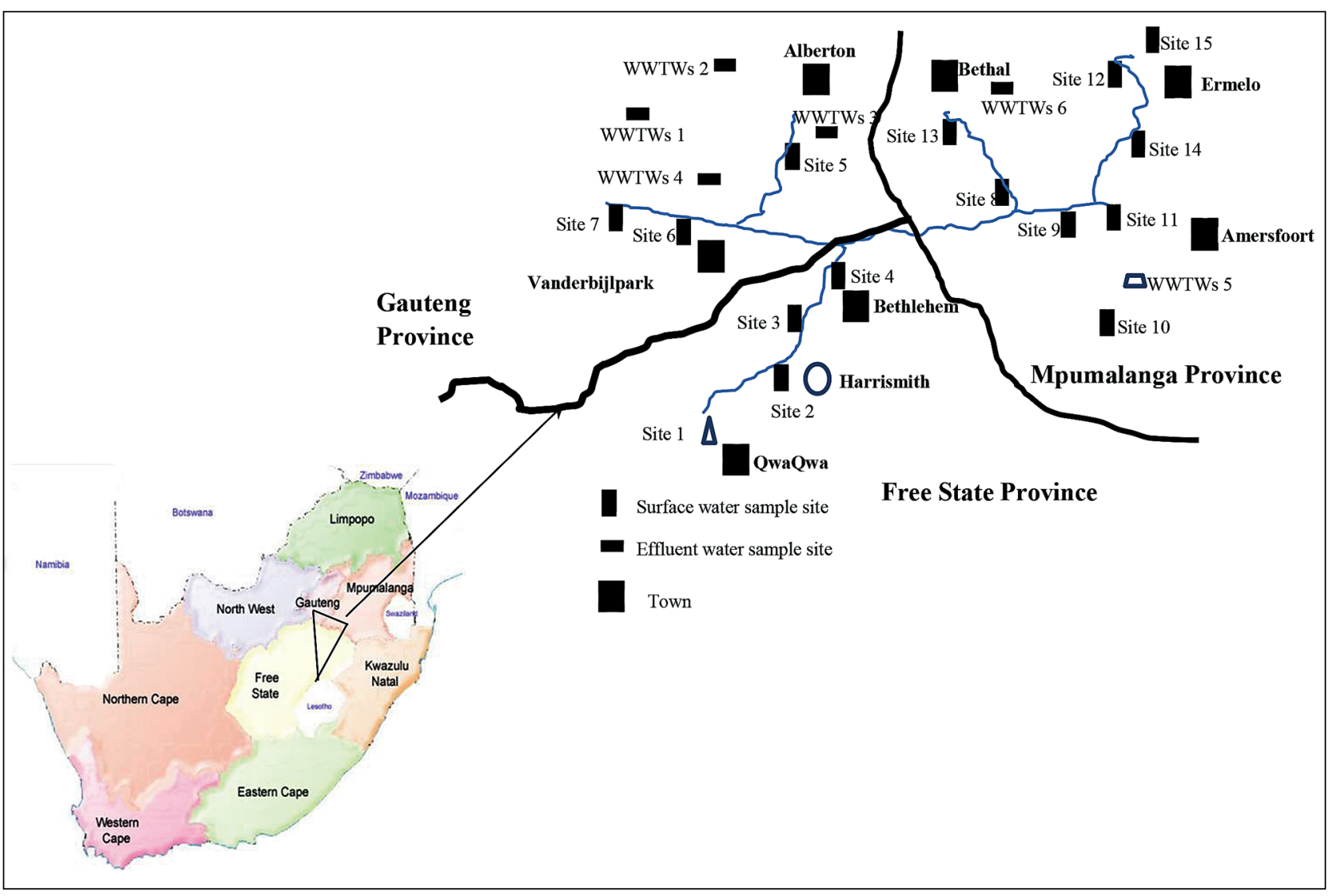

Figure 1. Map of South Africa (bottom) with expanded sampling sites (top) 
port was fitted with a SGE split/splitless liner; single taper with quartz wool $4 \mathrm{~mm}$ ID deactivated inlet liner (Restek, for Agilent GCs). The GC separation was conducted on a Restek RTx-1614, capillary column (film thickness $0.10 \mu \mathrm{m}, 15 \mathrm{~m} \times 0.25 \mathrm{~mm}$ I.D), (Chromspec cc South Africa)). The injections were made in splitless mode with the injector temperature set at $280^{\circ} \mathrm{C}$. The injection volume was $2 \mu \mathrm{L}$. The GC temperature programme conditions were as follows: initial temperature $90^{\circ} \mathrm{C}$, heated to $200^{\circ} \mathrm{C}$ by a temperature ramp of $20^{\circ} \mathrm{C} / \mathrm{min}$ then $230^{\circ} \mathrm{C}$ by a temperature ramp of $3^{\circ} \mathrm{C} / \mathrm{min}$ then finally heated to $300^{\circ} \mathrm{C}$ (held for $4 \mathrm{~min}$ ) by a temperature ramp of $60^{\circ} \mathrm{C} / \mathrm{min}$. Helium was used as carrier gas at a flow rate of $1.3 \mathrm{~mL} / \mathrm{min}$ and a constant linear velocity of $60 \mathrm{~cm} / \mathrm{s}$. For the MS, the ion source and transfer line temperatures of 150 and $300^{\circ} \mathrm{C}$, respectively, and ionization energy of $70 \mathrm{eV}$ were used. The monitored $\mathrm{m} / \mathrm{z}$ ions for each compound were obtained in full scan mode within the range 200-800 AMU with data acquired with ChemStation software (Agilent Technologies, Santa Clara, CA, USA).

\section{Quality assurance}

Since certified reference materials were not available, a spiking method was used to check the recoveries of analytes in the water samples. Recoveries were obtained by spiking $500 \mathrm{~mL}$ water sample with OPFRs standard mixture (200 ng/L (3-TCPP and TPP), $400 \mathrm{ng} / \mathrm{L}$ (TCEP, 1-TCPP and TCPP) and $1000 \mathrm{ng} / \mathrm{L}$ (TDCPP and TDBPP)). The spiked water sample was taken through the same extraction procedure prior to GC-MS analysis. TCEP, 1-TCPP and TCPP were detected above their respective LOQs in the blank samples (i.e. MilliQ water). The percentage recoveries in the spiked MilliQ water samples after background corrections ranged from $74.60 \pm 1.18$ (TCPP) $-108.67 \pm 9.19$ (TDBPP). Prior to the analysis of water samples, $100 \mathrm{ng} / \mathrm{L}$ Chlorpyrifos D10 was added into each sample as surrogate standard. The recovery of Chlorpyrifos D10 from all the samples ranged from $65-97 \%$. Several other quality assurance measures were routinely checked in this study and included analysing blanks in between samples, analysing a quality control sample after every 7 samples as well as analysing samples in triplicates.

The quantification of OPFRs was accomplished using internal standard method by relating the responses of OPFRs to the response of Parathion D10. The response factors were determined from the slope of a plot of the ratios of peak areas against the concentration levels. The values of plots were obtained from a 5-point analysis of the OPFRs standard solutions in the concentration range of $80-400 \mathrm{ng} / \mathrm{L}$ (3-TCPP and TPP); 160-800 ng/L (TCEP, 1-TCPP and TCPP) and 400-2 $000 \mathrm{ng} / \mathrm{L}$ (TDCPP and TDBPP). Limit of detection (LOD) was defined as a signal/noise ratio of 3 while the limit of quantification was defined as signal/noise ratio of 10 . For the compounds detected in blank samples, (TCEP, 1-TCPP and TDCPP), the LOD was calculated as mean blanks values plus 3 times the standard deviation. The following descriptive statistics: regression, sum, mean, median, minimum and maximum were calculated with Microsoft Excel 2010. Samples below LOD were treated as zero throughout the statistical analysis. The concentrations of analytes were expressed as ng/L and were not recovery corrected. All glassware was cleaned with laboratory wash solution, rinsed with distilled water, acetone and hexane.

\section{Risk assessment towards aquatic organisms}

In this study, risk assessment using risk quotients (RQs) for non-target organisms, as described by Cristale et al. (2013), were adopted. The RQs were calculated as the quotient of measured environmental concentration and the predicted no effect concentration (PNEC) using Eq. 1. PNEC was estimated as a quotient of toxicological relevance concentration and a security factor $(f)$ using Eq. 2.

$$
\mathrm{RQ}=\mathrm{MEC} / \mathrm{PNEC}
$$

$$
\mathrm{PNEC}=\mathrm{L}(\mathrm{E}) \mathrm{C} 50 / f
$$

where RQ is the risk quotient, MEC is the measured environmental concentration, PNEC is the predicted no effect concentration, $\mathrm{LC}_{50}$ is the lethal concentration required to kill $50 \%$, $\mathrm{EC}_{50}$ is the concentration of a toxicant which induces a response halfway between the baseline and maximum after a specified exposure time, and $f$ is the security factor.

For RQ calculations, the lowest $\mathrm{L}(\mathrm{E}) \mathrm{C}_{50}$ for fish, Daphnia and algae associated with TCEP, TCPP, TDCPP, TPP and TDBPP and a factor of 1000 were used (EC, 2003; Cristale et al., 2013; Shi et al., 2016). Table 1 presents the acute toxicity used for risk assessment.

For data interpretation, the maximum probable risk for ecological effect from contaminated water as prescribed (Wentsel et al., 1996; Cristale et al., 2013) was followed. RQ $<1$ indicates no significant risk; RQ between 1 and 10 indicates a small potential for adverse effects, RQs between 10 and 100 indicate a significant potential for adverse effects while RQs > 100 indicate that potential adverse effects should be expected.

\section{RESULTS AND DISCUSSION}

\section{Method performance and validation}

The recoveries of the spiked MilliQ water ranged from $74-108 \%$, for the surface water sample after background concentration correction ranged from $61-92 \%$, and the

\begin{tabular}{|c|c|c|c|c|c|c|c|c|c|}
\hline \multirow[b]{2}{*}{ Compound } & \multicolumn{3}{|c|}{ Fish } & \multicolumn{3}{|c|}{ Algae } & \multicolumn{3}{|c|}{ Daphnia } \\
\hline & $\begin{array}{l}\mathrm{L}(\mathrm{E}) \mathrm{C}_{50} \\
(\mathrm{mg} / \mathrm{L})\end{array}$ & Species & Ref & $\begin{array}{l}\mathrm{L}(\mathrm{E}) \mathrm{C}_{50} \\
(\mathrm{mg} / \mathrm{L})\end{array}$ & Species & Ref & $\begin{array}{l}\mathrm{L}(\mathrm{E}) \mathrm{C}_{50} \\
(\mathrm{mg} / \mathrm{L})\end{array}$ & Species & Ref \\
\hline TCEP & 90 & Carassius auratus & Verbruggen et al., 2005 & 51 & $\begin{array}{l}\text { Scenedesmus } \\
\text { subspicatus }\end{array}$ & Verbruggen et al., 2005 & 330 & Daphnia magna & Verbruggen et al., 2005 \\
\hline TCPP & 30 & Poecilia reticulata & Verbruggen et al., 2005 & 45 & $\begin{array}{l}\text { Scenedesmus } \\
\text { subspicatus }\end{array}$ & Verbruggen et al., 2005 & 91 & Daphnia magna & Verbruggen et al., 2005 \\
\hline TDCPP & 5.1 & Carassius auratus & Verbruggen et al., 2005 & 39 & $\begin{array}{c}\text { Pseudokirchnerialla } \\
\text { subcapitata }\end{array}$ & Verbruggen et al., 2005 & 4.2 & Daphnia magna & Verbruggen et al., 2005 \\
\hline TDBPP & 0.516 & Salmo gairdneri & NICNAS, 2005 & 0.545 & $\begin{array}{c}\text { Scenedesmus } \\
\text { abundans }\end{array}$ & NICNAS, 2005 & 4.568 & Daphnia magna & NICNAS, 2005 \\
\hline
\end{tabular}

Table 1. Acute toxicity ( $\mathrm{LC}_{50}$ or $\mathrm{EC}_{50}$ ) used for risk assessment for fish, Daphnia and algae 
recoveries from the spiked WWTWs effluent ranged from $57-81 \%$ with the RSD from all the water samples below $20 \%$. Except for the TDBPP results, the recoveries from all the samples were satisfactory, with the highest recoveries obtained from both MilliQ and surface water samples and a slightly lower recovery obtained from the WWTW effluent samples. The recovery of TDBPP was the highest from MilliQ water $(108 \%)$ followed by surface water at $61 \%$, with recovery from the WWTW effluent sample at $57 \%$. The recovery results are summarised in Table 2.

In order to evaluate the experimentally found optimum extraction conditions, MilliQ water was spiked at low and higher concentrations with the OPFRs standard mixture. At low concentration, the percentage recovery ranged from $66.6 \pm 13.4$ (TPP) $-128.7 \pm 1.1$ (TDBPP) while at higher concentration spike the percentage recoveries ranged from $60.8 \pm 13.3$ (TCPP) $-67.2 \pm 17.3$ (TDBPP) as shown in Table 3. Although the recoveries were lower as compared to the recoveries from lower concentration spikes, the results may indicate that at higher loading of the analytes there may be saturation on the cartridge. However, as the concentrations obtained in the current study were much lower than the concentration at higher loading, the results may be accepted. The RSD of the analytes from the high spiking concentration were all below $20 \%$, indicating a good repeatability of the extraction procedure. The calibration curves were linear $\left(r^{2}>0.975\right)$ across the concentration range as shown in Table 3. LOD and LOQ ranged from 4.2-24.0 ng/L and $13.9-80.3 \mathrm{ng} / \mathrm{L}$, respectively.

\section{Concentrations of OPFRs in surface water samples}

OPFRs were detected at all the sampling sites with detection frequency (\%DF) decreasing as follows: TDBPP (93.3\%) > TDCPP $(73.3 \%)>$ TCPP $(66.7 \%)>1-T C P P(60 \%)>$ TCEP
$(46.7 \%)>3$-TCPP $(40 \%)>$ TPP $(0 \%)$. Table 4 presents the contamination levels of OPFRs within the Vaal River. Low detection of TPP in surface water samples may be attributed to the fact that it has a higher $\log K_{\text {ow }}$ (i.e., 4.59) (Reemtsma et al., 2008 ) indicating its affinity to organic carbon. Also, a study by Marklund et al. (2005) indicated that TPP has an elimination rate of around $60 \%$ during wastewater treatment.

The mean concentrations of OPFRs within the Vaal River followed the following pattern: TDBPP $(228 \mathrm{ng} / \mathrm{L})>$ TCPP $(149 \mathrm{ng} / \mathrm{L})>$ TDCPP $(116 \mathrm{ng} / \mathrm{L})>1$-TCPP $(102 \mathrm{ng} / \mathrm{L})>$ TCEP $(31 \mathrm{ng} / \mathrm{L})>3$-TCPP $(25 \mathrm{ng} / \mathrm{L})$. The sum concentrations of OPFRs ( $\Sigma_{7}$ OPFRs) showed a $100 \%$ detection frequency from all the sampling sites with the concentrations ranging from 90-1 424 ng/L (mean 650 ng/L). Site 15 and Site 12 were the most polluted sampling sites within the Vaal River with concentrations of 1424 and $1360 \mathrm{ng} / \mathrm{L}$, respectively. These sampling sites are most influenced by industries present in the area. Another site that exhibited high concentrations of OPFRs was Site 13 which receives the effluent discharges from the Bethal area. The least polluted site was Site 10 with only TDCPP detected. The $\Sigma_{7}$ OPFRs from Site 4, Site 6, Site 8 and Site 11 were $267,314,306$ and $330 \mathrm{ng} / \mathrm{L}$ respectively. High variation in the concentrations of OPFRs at each site may be due to different industries in the vicinity together with limited sampling sites, especially in the Free State and Gauteng Provinces.

In comparison to the concentrations of OPFRs in surface water, the mean concentrations of TCEP $(31 \mathrm{ng} / \mathrm{L})$ were lower than the mean concentration obtained in Spain $(85 \mathrm{ng} / \mathrm{L})$ while the mean concentration of TDCPP (116 ng/L) obtained in our study was higher than the mean concentration (70 ng/L) obtained in surface water from Spain (Garcla-López et al., 2010). Martínez-Carballo et al. (2007) reported concentration ranges of 13-130 ng/L and < LOQ-19 ng/L for TCEP and TDCPP; respectively, in surface water from Austrian rivers.

Table 2. Recoveries of OPFRs in MilliQ water, surface water and WWTWs effluent water samples $(n=3)$

\begin{tabular}{|c|c|c|c|c|c|c|}
\hline \multirow{2}{*}{ Compound } & \multicolumn{2}{|c|}{ Spiked MilliQ water } & \multicolumn{2}{|c|}{ Surface water spiked } & \multicolumn{2}{|c|}{ WWTW effluent spiked } \\
\hline & Recovery (\%) & RSD (\%) & Recovery (\%) & RSD (\%) & Recovery (\%) & RSD (\%) \\
\hline TCEP & 89.9 & 1.9 & 82.2 & 6.9 & 70.1 & 6.5 \\
\hline 3-ТСРP & 77.1 & 1.7 & 75.9 & 5.9 & 81.7 & 10.2 \\
\hline 1-TCPP & 76.8 & 1.6 & 81.2 & 5.6 & 73.3 & 6.0 \\
\hline TCPP & 74.6 & 1.2 & 92.0 & 14.5 & 85.6 & 12.2 \\
\hline Chlorpyrifos D10 & 84.8 & 0.9 & 68.6 & 4.6 & 68.2 & 13.8 \\
\hline TDCPP & 81.6 & 4.9 & 67.9 & 9.7 & 64.0 & 6.0 \\
\hline TPP & 77.0 & 6.5 & 81.2 & 5.4 & 68.3 & 11.9 \\
\hline TDBPP & 108.7 & 9.2 & 61.8 & 5.4 & 57.2 & 4.8 \\
\hline
\end{tabular}

Table 3. Recoveries and RSD of OPFRs in MilliQ water $(n=3)$ and some of the validation parameters

\begin{tabular}{|c|c|c|c|c|c|c|c|c|}
\hline \multirow{3}{*}{ Compound } & \multicolumn{4}{|c|}{ Spiked MilliQ water } & \multicolumn{4}{|c|}{ Validation parameter } \\
\hline & \multicolumn{2}{|c|}{ Level 1} & \multicolumn{2}{|c|}{ Level 2} & \multirow{2}{*}{$\begin{array}{l}\text { Calibration } \\
\text { range (ng/L) }\end{array}$} & \multirow{2}{*}{$\begin{array}{c}\text { Linearity } \\
\qquad\left(r^{2}\right)\end{array}$} & \multirow{2}{*}{$\begin{array}{c}\text { LOD } \\
\text { (ng/L) }\end{array}$} & \multirow{2}{*}{$\begin{array}{l}\text { LOQ } \\
\text { (ng/L) }\end{array}$} \\
\hline & Recovery (\%) & RSD (\%) & Recovery (\%) & RSD (\%) & & & & \\
\hline TCEP & 87.2 & 0.8 & 64.4 & 9.1 & $160-800$ & 0.991 & 7.0 & 23.5 \\
\hline 3-ТCPP & 66.9 & 6.7 & 61.2 & 9.7 & $80-400$ & 0.999 & 4.2 & 13.9 \\
\hline 1-ТCPP & 73.4 & 12.4 & 61.9 & 13.5 & $160-800$ & 0.999 & 9.1 & 31.1 \\
\hline TCPP & 77.5 & 2.5 & 60.8 & 13.3 & $160-800$ & 0.979 & 10.6 & 35.4 \\
\hline Chlorpyrifos D10 & 67.6 & 3.9 & 73.9 & 13.1 & $40-200$ & N/A & N/A & N/A \\
\hline TDCPP & 92.1 & 1.5 & 61.6 & 5.7 & $400-2000$ & 0.994 & 13.8 & 45.9 \\
\hline TPP & 66.6 & 13.4 & 62.3 & 3.9 & $80-400$ & 0.997 & 6.2 & 20.4 \\
\hline TDBPP & 128.7 & 1.4 & 67.2 & 17.3 & $400-2000$ & 0.975 & 24.0 & 80.3 \\
\hline
\end{tabular}

N/A: not applicable

Level 1: $100 \mathrm{ng} / \mathrm{L}$ (3-TCPP and TPP), $200 \mathrm{ng} / \mathrm{L}$ (TCEP, 1-TCPP and TCPP) and $500 \mathrm{ng} / \mathrm{L}$ (TDCPP and TDBPP) were spiked into 500 mL of MilliQ water Level 2: $340 \mathrm{ng} / \mathrm{L}$ (3-TCPP and TPP), $680 \mathrm{ng} / \mathrm{L}$ (TCEP, 1-TCPP and TCPP) and $1700 \mathrm{ng} / \mathrm{L}$ (TDCPP and TDBPP) were spiked into 500 mL of MilliQ water 
Table 4. Mean concentrations of OPFRs within the Vaal River catchment

\begin{tabular}{|c|c|c|c|c|c|c|c|c|}
\hline Site & $\begin{array}{l}\text { TCEP } \\
\text { (ng/L) }\end{array}$ & $\begin{array}{c}\text { 3-TCPP } \\
\text { (ng/L) }\end{array}$ & $\begin{array}{l}\text { 1-TCPP } \\
\text { (ng/L) }\end{array}$ & $\begin{array}{c}\text { TCPP } \\
\text { (ng/L) }\end{array}$ & $\begin{array}{l}\text { TDCPP } \\
\text { (ng/L) }\end{array}$ & $\begin{array}{c}\mathrm{TPP} \\
(\mathrm{ng} / \mathrm{L})\end{array}$ & $\begin{array}{l}\text { TDBPP } \\
\text { (ng/L) }\end{array}$ & $\begin{array}{c}\sum_{7} \text { OPFRs } \\
\text { (ng/L) }\end{array}$ \\
\hline Site 1 & nd & 16.0 & 20.2 & 96.1 & 116.2 & nd & 270.4 & 518.9 \\
\hline Site 2 & 37.4 & nd & 19.9 & 0.010 & 54.7 & nd & 663.9 & 775.6 \\
\hline Site 3 & nd & 61.0 & 265.8 & 289.1 & nd & nd & 134.7 & 750.6 \\
\hline Site 4 & nd & nd & nd & 21.7 & 47.6 & nd & 198.1 & 267.4 \\
\hline Site 5 & 70.0 & 110.0 & 110.0 & 198.2 & 130.0 & nd & 170.0 & 788.2 \\
\hline Site 6 & 40.0 & nd & 0.0 & nd & 130.0 & nd & 143.6 & 313.6 \\
\hline Site 7 & 60.0 & 60.0 & 40.0 & 120.0 & 140.0 & nd & 189.3 & 609.3 \\
\hline Site 8 & nd & nd & nd & nd & 93.6 & nd & 212.5 & 306.1 \\
\hline Site 9 & nd & nd & 70.3 & 334.1 & nd & nd & 277.3 & 681.7 \\
\hline Site 10 & nd & nd & nd & nd & 90.0 & nd & nd & 90.0 \\
\hline Site 11 & nd & nd & nd & 50.0 & 100.0 & nd & 180.0 & 330.0 \\
\hline Site 12 & 235 & 34.3 & 34.8 & 165.3 & 624.4 & nd & 266.7 & 1360.6 \\
\hline Site 13 & 20.5 & 91.4 & 398.0 & 389.1 & nd & nd & 116.1 & 1015.1 \\
\hline Site 14 & nd & nd & nd & nd & 212.2 & nd & 301.7 & 513.9 \\
\hline Site 15 & nd & nd & 568.3 & 566.2 & 0.0 & nd & 289.3 & 1423.8 \\
\hline$\% D F$ & 46.7 & 40 & 60 & 66.7 & 73.3 & nd & 93.3 & 100 \\
\hline Range & $\mathrm{nd}-235$ & nd - 110 & $\mathrm{nd}-568$ & $n d-566$ & $\mathrm{nd}-624$ & nd & $n d-664$ & $90-1424$ \\
\hline Mean & 31 & 25 & 102 & 149 & 116 & nd & 228 & 650 \\
\hline Median & 0.0 & 0.0 & 20 & 96 & 94 & nd & 198 & 609 \\
\hline
\end{tabular}

Bold: results that are discussed in the report; DF: detection frequency; $n d$ : not detected

Higher concentration, ranging from 113-26 $050 \mathrm{ng} / \mathrm{L}$ for TCPP, were reported in surface water from the River Aire in the UK (Cristale et al., 2013). In the same study, a TCEP range of 119-316 ng/L was observed, which was similar to the results obtained in our study. Concentration ranges of 38-3 $700 \mathrm{ng} / \mathrm{L}$ were reported from Songhua River, China (Wang et al., 2011). Shi et al. (2016) reported ranges of < LOD-2 $072 \mathrm{ng} / \mathrm{L}$ (mean $291 \mathrm{ng} / \mathrm{L}$ ) and < LOD-855 (mean $46.3 \mathrm{ng} / \mathrm{L}$ ) for TCEP and TDCPP in surface water from Beijing respectively. The TDCPP results were similar to the results obtained in our study while the TCEP values were almost 10 times higher than the results obtained in this study.

\section{Concentrations of OPFRs in WWTWs effluents}

The detection frequency of OPFRs in final effluents of WWTWs were as follows: 1-TCPP/ TCPP (100\%) > TCEP/ 3-TCPP/ TDBPP $(83.3 \%)>$ TDCPP $(16.7 \%)>$ TPP $(0 \%)$. The mean concentrations ( $997 \mathrm{ng} / \mathrm{L})$ of OPFRs in effluent samples were higher than the mean concentrations $(650 \mathrm{ng} / \mathrm{L})$ obtained in surface water, indicating that the presence of OPFRs in surface water may be attributed to effluents from WWTWs. Table 5 presents the concentrations of OPFRs in effluents samples from WWTWs.

The summed concentrations of OPFRs ranged from 345-2073 ng/L in effluent samples. The highest $\Sigma_{7}$ OPFRs concentrations were detected in WWTW6 which treats both the domestic and industrial wastewaters from the Bethal area in Mpumalanga. It was followed by WWTW3 at $1168 \mathrm{ng} / \mathrm{L}$ which also treats both domestic and industrial wastewaters in the Gauteng region. In all the effluents analysed, 1-TCPP and TCPP were the most abundant OPFRs with mean concentrations of $300 \mathrm{ng} / \mathrm{L}$ and $364 \mathrm{ng} / \mathrm{L}$, respectively. The higher abundance of TCPP in comparison to TCEP may be attributed to industrial replacement of TCEP by TCPP used in flexible foam in Europe (EC, 2003; Quednow and Püttmann, 2009). These results from our study supported the finding by Andresen et al. (2004) and Martínez-Carballo et al. (2007) indicating WWTWs effluents as a source of OPFRs in surface water.

Table 5. Concentrations of OPFRs in effluent water samples

\begin{tabular}{|c|c|c|c|c|c|c|c|c|}
\hline Site & $\begin{array}{l}\text { TCEP } \\
\text { (ng/L) }\end{array}$ & $\begin{array}{c}\text { 3-TCPP } \\
\text { (ng/L) }\end{array}$ & $\begin{array}{l}\text { 1-TCPP } \\
\text { (ng/L) }\end{array}$ & $\begin{array}{c}\text { TCPP } \\
\text { (ng/L) }\end{array}$ & $\begin{array}{l}\text { TDCPP } \\
\text { (ng/L) }\end{array}$ & $\begin{array}{c}\text { TPP } \\
\text { (ng/L) }\end{array}$ & $\begin{array}{l}\text { TDBPP } \\
\text { (ng/L) }\end{array}$ & $\begin{array}{c}\sum_{7} \text { OPFRs } \\
\text { (ng/L) }\end{array}$ \\
\hline WWTW1 & 120.6 & 0.0 & 85.9 & 420.2 & 0.0 & 0.0 & 290.5 & 917.2 \\
\hline WWTW2 & 79.2 & 20.5 & 42.6 & 202.7 & 0.0 & 0.0 & 0.0 & 345.1 \\
\hline WWTW3 & 15.8 & 77.9 & 316.4 & 280.9 & 0.0 & 0.0 & 476.8 & 1167.8 \\
\hline WWTW4 & 0.0 & 27.4 & 379.9 & 318.3 & 0.0 & 0.0 & 182 & 907.8 \\
\hline WWTW5 & 110.0 & 20.0 & 60.0 & 110.0 & 120.0 & 0.0 & 150.0 & 570.0 \\
\hline WWTW6 & 19.7 & 61.6 & 916 & 849.6 & 0.0 & 0.0 & 226.3 & 2073.1 \\
\hline$\% D F$ & 83.3 & 83.3 & 100 & 100 & 16.7 & 0.00 & 83.3 & 100 \\
\hline Min & $<\mathrm{LOQ}$ & $<\mathrm{LOQ}$ & 43 & 110 & $<\mathrm{LOQ}$ & $<\mathrm{LOQ}$ & $<\mathrm{LOQ}$ & 345 \\
\hline Max & 121 & 78 & 916 & 850 & 120 & 0.00 & 477 & 2073 \\
\hline Mean & 58 & 35 & 300 & 364 & 20 & 0.00 & 221 & 997 \\
\hline Median & 49 & 24 & 201 & 300 & 0.00 & 0.00 & 204 & 912 \\
\hline
\end{tabular}

Bold: results that are discussed in the report; DF: detection frequency; LOQ: limit of quantification 
In comparison with results for effluents from other parts of the world, higher mean concentrations of TCPP in WWTWs effluents from Sweden and Germany (4 $400 \mathrm{ng} / \mathrm{L}$ and 3 $000 \mathrm{ng} / \mathrm{L}$, respectively) were reported (Marklund et al., 2005; Meyer and Bester, 2004). TCEP concentration (350 ng/L) was reported by Marklund et al. (2005) in effluents from Sweden. From Spanish wastewater samples, a similar concentration range for TCPP (290-680 ng/L) was reported (Garcla-López et al., 2010). The TCPP concentration results from our study were comparable to the TCPP concentration (290-1 $400 \mathrm{ng} / \mathrm{L})$ reported from Austrian WWTP effluents (Martínez-Carballo et al., 2007). TCEP, TCPP, TDCPP and TDBPP were detected at concentrations of $133 \mathrm{ng} / \mathrm{L}, 440 \mathrm{ng} / \mathrm{L}, 227 \mathrm{ng} / \mathrm{L}$ and not detected; respectively, in WWTWs effluents from Canada (Woudneh et al., 2015).

\section{Risk to aquatic life}

In this study, the risk assessment for aquatic organisms was estimated for the detected OPFRs, including, TCEP, TCPP (total of 3-TCPP, 1-TCPP and TCPP), TDCPP and TDBPP in surface water samples. No significant risk $(\mathrm{RQ}<1)$ was observed within the Vaal River catchment associated to TCEP, TCPP, TDCPP and TDBPP for any of the three organisms. RQs for TCEP, TCPP, TDCPP and TDBPP varied from 0.0006-0.418 for algae; from 0.00009-0.0499 for Daphnia, and from 0.00030.442 for fish, respectively. However, to estimate the joint effect of OPFRs within the Vaal River catchment the sum of RQs derived from each site of the detected compound were used (Cristale et al., 2013). Table 6 presents the summed RQs of the OPFRs for the chosen three aquatic organisms, following the recommendation of the Technical Guidance Document on Risk Assessment (EC, 2003) that requires at least three trophic levels from the assessed environment.

The risk assessment from Site 2 showed a low potential for adverse effects $(1.0 \leq \mathrm{RQ} \leq 10)$ for fish and algae with RQ values of 1.298 and 1.221 ; respectively. The rest of the sampling sites showed no significant risk $(\mathrm{RQ} \leq 1.0)$ from OPFRs for algae, Daphnia and fish. The summed RQ values ranged from $0.248-1.221,0.0363-0.2106$ and $0.0176-1.298$ for algae, Daphnia and fish; respectively. Though risk assessment was low for OPFRs, more monitoring studies should be undertaken

Table 6. Summed RQ results for OPFRs from each sampling site within the Vaal River catchment for algae, Daphnia and fish

\begin{tabular}{lccc}
\hline \multirow{2}{*}{ Site } & \multicolumn{3}{c}{ Summed RQs } \\
\cline { 2 - 4 } & Algae & Daphnia & Fish \\
\hline Site 1 & 0.527 & 0.0884 & 0.625 \\
Site 2 & 1.221 & 0.1586 & 1.294 \\
Site 3 & 0.261 & 0.0363 & 0.285 \\
Site 4 & 0.248 & 0.0549 & 0.394 \\
Site 5 & 0.326 & 0.0730 & 0.372 \\
Site 6 & 0.267 & 0.0625 & 0.304 \\
Site 7 & 0.357 & 0.0770 & 0.402 \\
Site 9 & 0.518 & 0.0651 & 0.551 \\
Site 10 & 0.002 & 0.0214 & 0.0176 \\
Site 11 & 0.334 & 0.0244 & 0.370 \\
Site 12 & 0.515 & 0.2106 & 0.540 \\
Site 13 & 0.233 & 0.0351 & 0.254 \\
Site 14 & 0.559 & 0.1165 & 0.626 \\
Site 8 & 0.392 & 0.0688 & 0.430 \\
Site 15 & 0.558 & 0.0758 & 0.599 \\
\hline
\end{tabular}

as studies have shown that most of the halogenated OPFRs are not removed during wastewater treatment (Reemtsma et al., 2008) and similar processes (biodegradation and sorption) affect their concentrations and fate in the dissolved phase. In addition, recent studies have reported the presence of OPFRs in biota (Kim et al., 2011; Sundkvist et al., 2010) indicating that OPFRs can be accumulated in biota. Thus further studies on bio-accumulation and bio-magnification of OPFRs in biota from aquatic environments for comprehensive risk assessment is of outmost importance.

\section{CONCLUSIONS}

In the present study, the concentrations and risk assessment of OPFRs in surface and effluent water samples within the Vaal River catchment were reported. Six of the seven OPFRs were detected in the surface water samples with TCPP (all of the three studied isomers) and TDBPP detected at higher concentrations followed by TDCPP and TCEP. TPP was not detected in all samples. The same pattern in concentration was observed in effluent samples, albeit at high concentrations. Risk assessment based on acute toxicity data on three aquatic organisms (i.e. algae, Daphnia and fish) suggested no significant risk in most of the sampling sites. However, the joint effect of OPFRs derived from the sum of RQs from one site in our study indicated a low potential for adverse effect on algae and fish. Taking into account the high levels of these pollutants in WWTW effluents, long-term exposure and bioaccumulation of these OPFRs and other emerging flame retardants in the aquatic environment indicates that further studies are needed to define the environmental risk produced by these pollutants.

\section{ACKNOWLEDGEMENTS}

The authors would like to thank Rand Water - Analytical Services for providing a technical environment for the project. The authors also declare there is no conflict of interest.

\section{REFERENCES}

ABAFE OA and MARTINCIGH BS (2014) Organophosphorus flame retardants and plasticizers in dust from automobile, homes, offices and university classrooms: implications for personal exposure via inadvertent dust ingestion. Organohalogen Compounds 76 277-280.

ANDRESEN JA, GRUNDMANN A and BESTER K (2004) Organophosphorus flame retardants and plasticizers in surface waters. Sci. Total Environ. 332 155-166. https://doi.org/10.1016/j. scitotenv.2004.04.021

BETH-HUBNER M (1999) Toxicological evaluation and classification of the genotoxic, carcinogenic, repro-toxic and sensitizing potential of tris-(2-chloroethyl)-phosphate. Int. Arch. Occup. Environ. Health 72 M17-M23. https://doi.org/10.1007/pl00014210

CHOKWE TB, OKONKWO JO and NWAMADI MS (2017) Occurrence and distribution of tetrabromobisphenol A and its derivative in river sediments from Vaal River catchment, South Africa. Emerging Contam. 3 121-126. https://doi.org/10.1016/j. emcon.2017.11.001

CRISTALE J, KATSOYIANNIS A, SWEETMAN AJ, JONES KC and LACORTE S (2013) Occurrence and risk assessment of organophosphorus and brominated flame retardants in the river Aire (UK). Environ. Pollut. 179 194-200.

DISHAW LV, POWERS CM, RYDE IT, ROBERTS SC, SEIDLER FJ, SLOTKIN TA and STAPLETON HM (2011) Is the PentaBDE replacement, tris (1,3-dichloro-2-propyl) phosphate (TDCIPP), a developmental neurotoxicant? Studies in PC12 cells. Toxicol. Appl. Pharmacol. 256 (3) 281-289. https://doi.org/10.1016/j. taap.2011.01.005 
EGUCHI A, ISOBE T, RAMU K, TUE NM, SUDARYANTO A, DEVANATHAN G, VIET PH, TANA RS, TAKAHASHI S, SUBRAMANIAN A and TANABE S (2013) Soil contamination by brominated flame retardants in open waste dumping sites in Asian developing countries. Chemosphere 90 2365-2375. https://oi. org/10.1016/j.chemosphere.2012.10.027

EUROPEAN COMMISSION (EC) (2003) Technical Guidance Document on Risk Assessment in Support of Commission Directive 93/67/EEC on Risk Assessment for New Notified Substances, Commission Regulation (EC) No 1488/94 on Risk Assessment for Existing Substances, Directive 98/8/EC of the European Parliament and of the Council Concerning the Placing of Biocidal Products on the Market. Part II. https://doi. org/10.1002/352760197x.app1

EUROPEAN FLAME RETARDANTS ASSOCIATION (EFRA) (2006) Phosphorous - Alkyl Halogenated Phosphate Esters. URL: http://www.flameretardants.eu/DocShareNoFrame/docs/3/ FDEFAGLBNLDPLEBJDILIMBHJPIB146H7BOHKKK4N1KBO/ EFRA/docs/DLS/2HalogenatedPhosphateEstersFactSheetAB-1_00. pdf (Accessed September 2017).

GAO Z, DENG Y, YUAN W, HE H, YANG S and SUN C (2014) Determination of organophosphorus flame retardants in fish by pressurized liquid extraction using aqueous solutions and solid phase microextraction coupled with gas chromatograph-flame photometric detector. J. Chromatogr. A 1366 31-37. https://doi. org/10.1016/j.chroma.2014.09.028

GARCÍA-LÓPEZ M, RODRÍGUEZ I and CELA R (2010) Mixed-mode solid-phase extraction followed by liquid chromatography-tandem mass spectrometry for the determination of tri- and di-substituted organophosphorus species in water samples. J. Chromatogr. A 1217 1476-1484. https://doi.org/10.1016/j.chroma.2009.12.067

KEMMLEIN S, HAHN O and JANN O (2003) Emissions of organophosphate and brominated flame retardants from selected consumer products and building materials. Atmos. Environ. 37 5485-5493. https://doi.org/10.1016/j.atmosenv.2003.09.025

KIM JW, ISOBE T, CHANG KH, AMANO A, MANEGA RH, ZAMORA PB, SIRINGAN FP and TANABE S (2011) Levels and distribution of organophosphorus flame retardants and plasticizers in fishes from Manila Bay, the Philippines. Environ. Pollut. 159 3653-3659. https://doi.org/10.1016/j.envpol.2011.07.020

KIM JW, ISOBE T, SUDARYANTO A, MALARVANNAN G, CHANG KH, MUTO M, PRUDENTE M and TANABE S (2013) Organophosphorus flame retardants in house dust from the Philippines: occurrence and assessment of human exposure. Environ. Sci. Pollut. Res. 20 (2) 812-822. https://doi.org/10.1007/ s11356-012-1237-X

LI J, YU N, ZHANG B, JIN L, LI M, HU M, ZHANG X, WEI S and YU H (2014) Occurrence of organophosphorus flame retardants in drinking water from China. Water Res. 54 53-61. https://doi. org/10.1016/j.watres.2014.01.031

LIN K (2009) Joint acute toxicity of tributyl phosphate and triphenyl phosphate to Daphnia magna. Environ. Lett. 7 (4) 309-312. https:// doi.org/10.1007/s10311-008-0170-1

MARKLUND A, ANDERSSON B and HAGLUND P (2005) Organophosphorus flame retardants and plasticizers in Swedish sewage treatment plants. Environ. Sci. Technol. 39 7423-7429. https://doi.org/10.1021/es0510131

MARTÍNEZ-CARBALLO E, GONZÁLEZ-BARREIRO C, SITKA A, SCHARF S and GANS O (2007) Determination of selected organophosphate esters in the aquatic environment of Austria. Sci. Total Environ. 388 290-299. https://doi.org/10.1016/j. scitotenv.2007.08.005

MEYER J and BESTER K (2004) Organophosphate flame retardants and plasticizers in wastewater treatment plants. J. Environ. Monit. 6 599-605.

MORRIS PJ, MEDINA-CLEGHORN D, HESLIN A, KING SM, ORR J, MULVIHILL MM, KRAUSS RM and NOMURA DK (2014) Organophosphorus flame retardants inhibit specific liver carboxylesterases and cause serum hypertriglyceridemia. Chem. Biol. 9 1097-1103. https://doi.org/10.1021/cb500014r

MÖLLER A, XIE Z, CABA A, STURM R and EBINGHAUS R (2011) Organophosphorus flame retardants and plasticizers in the atmosphere of the North Sea. Environ. Pollut. 159 (12) 3660-3665. https://doi.org/10.1016/j.envpol.2011.07.022

NICNAS (National Industrial Chemicals Notification and Assessment Scheme) (2005). Priority Existing Chemical Assessment Report No. 27. URL: https://www.nicnas.gov.au/__data/assets/word_ doc/0020/34832/PEC27-TBBP.docx (Accessed September 2017).

OLIVERI AN, BAILEY JM and LEVINA ED (2015) Developmental exposure to organophosphate flame retardants causes behavioral effects in larval and adult Zebrafish. Neurotoxicol. Teratology 52 220-227. https://doi.org/10.1016/j.ntt.2015.08.008

QUEDNOW K and PÜTTMANN W (2009) Temporal concentration changes of DEET, TCEP, terbutryn, and nonylphenols in freshwater streams of Hesse, Germany: possible influence of mandatory regulations and voluntary environmental agreements. Environ. Sci. Pollut. Res. 16 630-640. https://doi.org/10.1007/s11356-009-0169-6

REEMTSMA T, GARCÍA-LÓPEZ M, RODRÍGUEZ I, QUINTANA JB and RODIL R (2008) Organophosphorus flame retardants and plasticizers in water and air I. Occurrence and fate. Trends Anal. Chem. 27 727-737. https://doi.org/10.1016/j.trac.2008.07.002

SATO T, WATANABE K, NAGASE H, KITO H, NIIKAWA M, and YOSHIOKA Y (1997) Investigation of the hemolytic effects of various organophosphoric acid triesters (OPEs) and their structureactivity relationship. Toxicol. Environ. Chem. 29 277-287. https:// doi.org/10.1080/02772249709358444

SHI Y, GAO L, LI W, WANG Y, LIU J and CAI Y (2016) Occurrence, distribution and seasonal variation of organophosphate flame retardants and plasticizers in urban surface water in Beijing, China. Environ. Pollut. 209 1-10. https://doi.org/10.1016/j. envpol.2015.11.008

SHOEIB M, AHRENS L, JANTUNEN L and HARNER T (2014) Concentrations in air of organobromine, organochlorine and organophosphate flame retardants in Toronto, Canada. Atmos. Environ. 99 140-147. https://doi.org/10.1016/j.atmosenv.2014.09.040

SUNDKVIST AM, OLOFSSON U and HAGLUND P (2010)

Organophosphorus flame retardants and plasticizers in marine and fresh water biota and in human milk. J. Environ. Monit. 12 943-951. https://doi.org/10.1039/b921910b

VAN DER VEEN I and DE BOER J (2012) Phosphorus flame retardants: properties, production, environmental occurrence, toxicity and analysis. Chemosphere 88 1119-1153. https://doi. org/10.1016/j.chemosphere.2012.03.067

VERBRUGGEN EMJ, RILA JP, TRAAS TP, POSTHUMADOODEMAN, CJAM and POSTHUMUS R (2005) Environmental risk limits for several phosphate esters, with possible application as flame retardant. RIVM Report 601501024/2005. National Institute for Public Health and the Environment, Bilthoven.

WANG Q, LAM JCW, MAN YC, LAI NLS., KWOK KY, GUO YY, LAM PK and ZHOU B (2015) Bioconcentration, metabolism and neurotoxicity of the organophosphorus flame retardant 1,3-dichloro 2-propyl phosphate (TDCPP) to Zebrafish. Aquat. Toxicol. 158 108-115. https://doi.org/10.1016/j.aquatox.2014.11.001

WANG XW, LIU JF and YIN YG (2011) Development of an ultra-highperformance liquid chromatography-tandem mass spectrometry method for high throughput determination of organophosphorus flame retardants in environmental water. J. Chromatogr. A 1218 6705-6711. https://doi.org/10.1016/j.chroma.2011.07.067

WEI GL, LI DQ, ZHUO MN, LIAO YS, XIE ZY, GUO TL, LI JJ, ZHANG SY and LIANG ZQ (2015) Organophosphorus flame retardants and plasticizers: sources, occurrence, toxicity and human exposure. Environ. Pollut. 196 29-46. https://doi. org/10.1016/j.envpol.2014.09.012

WENTSEL RS, LAPOINT TW, SIMINI M, CHECKAIL RT, LUDWIG D and BREWER, L (1996) Tri-service Procedural Guidelines for Ecological Risk Assessment. US Army Edgewood Research, Development, and Engineering Center, Aberdeen Proving Ground, MD. https://doi.org/10.21236/ada427056

WHO (World Health Organization) (1991) Environmental Health Criteria 111. Triphenyl phosphate. WHO, Geneva.

WOUDNEH MB, BENSKIN JP, WANG G, GRACE R, HAMILTON MC and COSGROVE JR (2015) Quantitative determination of 13 organophosphorus flame retardants and plasticizers in a wastewater treatment system by high performance liquid 
chromatography tandem mass spectrometry. J. Chromatogr. A 1400 149-155. https://doi.org/10.1016/j.chroma.2015.04.026

ZENG L, YANG R, ZHANG Q, ZHANG H, XIAO K, ZHANG H,

WANG Y, LAM PK and JIANG G (2014a) Current levels and

composition profiles of emerging halogenated flame retardants and dehalogenated products in sewage sludge from municipal wastewater treatment in China. Environ. Sci. Technol. $4812586-$ 12594. https://doi.org/10.1021/es503510q
ZENG X, HE L, CAO S, MA S, YU Z, GUI H, SHENG G and FU J (2014b) Occurrence and distribution of organophosphorus flame retardants/ plasticizers in wastewater treatment plant sludge from the Pearl River Delta, China. Environ. Toxicol. Chem. 331720 1725. https://doi.org/10.1002/etc. 2604 